\title{
VOTING RIGHTS AND INTERGENERATIONAL JUSTICE: FRAMING EFFECTS AND VOTER ATTITUDES
}

\author{
BÉLA JANKY - ATTILA GULYÁS
}

\begin{abstract}
We investigate attitudes toward voting reforms that attribute greater weight to younger generations in a survey experiment. The main assumption of this research is that due to the distortions caused by elite discourse, voters are not aware of the intergenerational inequality of redistribution, thus attempts to change the voting system - that currently provides an equal vote to each voter, thereby maintaining inequality - would not get sufficient public support.

After providing a review of potential voting reforms for improving intergenerational justice, we present results from an online survey sample of one thousand respondents. The data show that presenting the arguments for intergenerational justice increases the sensitivity of younger voters towards the political rights of young generations, but does not improve the acceptance of such reforms among the middle-aged and the elderly.
\end{abstract}

KEYWORDS: intergenerational justice, voting right, survey-experiment, Hungary

\section{INTRODUCTION}

Our study examines support for voting-rights reforms that could better represent the interests of young and future generations compared to current voting systems based on equal votes. These reforms include giving additional votes to families with children; increasing the weight attributed to younger

1 Béla Janky is a senior research fellow at the Centre for Social Research of the Hungarian Academy of Sciences (HAS), and associate professor at the Dept. of Sociology and Communication of the Budapest University of Technology and Economics (BME), Attila Gulyás is a senior research fellow at the HAS; e-mails: janky@eik.bme.hu, gulyas.attila@tk.mta.hu 
voters; and decreasing the voting age. We do not focus on the sociodemographic background to the current attitudes. Rather, we investigate the relationship between public discourse and support for the such voting-rights reforms.

The research question employed in the study concerned how the framing of state redistribution mechanisms affects the sensitivity of young generations to the voting rights of future generations. The main methodology for this research was a framing survey experiment involving respondents reacting to the survey after having been presented with specific forms of information about redistribution-related dilemmas.

First, we assume that in the public discourse about the role of the state the intergenerational aspects of state redistribution are usually neglected. Therefore, voters do not perceive the intergenerational injustice of current welfare regimes, resulting in their being insensitive to the intergenerational justice coded into the current voting system. Survey-based experiments can simulate the longterm effects of complex discourses to a certain extent, as well as the short-term effects of presenting several aspects of the problem to respondents. Using such a survey experiment with pre-survey framing we were able to investigate these effects. We assume that such an analysis could help with understanding the role of public discourses on attitudes.

In our experiment the online sample of one thousand adults were split into four groups of equal size. The first group of respondents answered three questions related to voting-rights reforms without any manipulations, and thus served as the control group. The questions focused on support for voting-rights reforms that award greater voting weight to younger generations. Another randomly generated group watched a short framing video that discussed state redistribution dilemmas in line with the current public discourse before completing the survey, which also contained a few attitude-related questions before the questions on voting-rights reforms. The framing video for this group highlighted the intragenerational aspects of redistribution, including the dilemmas involved in supporting the poor via taxation of the working population.

The third random group was presented with information similarly framed, but in their case the framing video highlighted intergenerational redistribution issues through presenting the dilemma of making elderly or large families the beneficiaries of redistribution.

The fourth group did not watch a framing video but were exposed to some priming questions in their survey that intentionally conflated Roma people with large families and those on welfare before the questions about voting rights.

Our results partially confirm our expectations, and suggest that presenting information about aspects of intergenerational redistribution does increase the sensitivity of younger respondents to the political rights of younger generations, 
but does not decrease the overall level of rejection of voting-rights reforms among the middle-aged and the elderly. An interesting result is that better educated respondents are more likely to reject such reforms than less educated respondents.

In the following section we review issues surrounding intergenerational justice and the reforms of voting rights that have been proposed in this domain. These suggestions served as a basis for the survey. We then describe the theories and results used to formulate our hypotheses that explain voter preferences relating to the dilemmas of intergenerational redistribution. The following two sections present the methodology and the results. We conclude by summarizing our results and giving an overview of the lessons learned during this work.

\section{INTERGENERATIONAL JUSTICE: THE CLASHING INTERESTS OF GENERATIONS}

Our research focuses on the potential for voting-rights reforms that ensure the representation of future generations' interests to a much greater degree than current systems. Here, we do not aim to give a detailed analysis, but rather constrain ourselves to a discussion of the political possibilities of these reforms.

The decisions of current generations influence future generations' possibilities negatively in many aspects. The most frequently mentioned domains are environmental problems (Arnell 1999; Hackl and Pruckner 2003; Lumer 2009) and the fiscal policies that lead to the accumulation of public debt (Alesina and Tabellini 1990; Kopits 2007; Penner and Steuerle 2007). In the current decade not only has the concept of intergenerational justice became more prominent in these domains, but several indicators have been developed to allow related comparisons across countries (McQuilkin 2018; Vanhuysse 2013b).

The importance of environmental factors is widely accepted today among the majority, yet the policies that are designed to save natural resources and react to climate change are often rejected due to the conflicting interests of private consumption. Put another way, this involves a collective action dilemma: individuals create a "public bad" - although they know what should be done, they are not willing to do it (Hauert, Wakano, and Doebeli 2008). This is despite the fact that over the last two decades (due to the rise in awareness about these issues) governmental actors have put considerable effort into conserving the Earth's natural state and dealing with the challenge of the overuse of natural resources, with the support of most of the public of developed countries.

Although the environment is a key topic in intergenerational justice and ideas about sustainable development, our research focuses on another similarly 
important issue that receives much less attention in public discourse: the effect of state overspending on future generations; or, in other words, accumulating government debt and other related fiscal balance issues (Buchanan and Wagner 1977; Kopits 2007). Usually, decisions about public or governmental debt levels are considered under this topic, yet many consider the individual-level dilemma of childbearing to involve similar challenges. The former dilemma involves the accumulation of state debt and the sustainability of pension systems (Noord 1993). State debt presents a threat to intergenerational justice, as for sustaining present generations in the future, the taxes and social contributions of future generations will be spent. This situation can be thought of as a sustainability issue for pension systems: active generations will need to provide such levels of support to elderly generations that they will not be able to support themselves as pensioners given current demographic trends (or only through increased tax burdens on future generations).

Our research question concerns how voters relate to the inequalities in the intergenerational redistribution of state expenditure. This dilemma has already been discussed by numerous economists in the domain of political behavior and state redistribution in the last decades by using the "selfish voter" model to explain redistribution outcomes. The basis of the rational voter model, meanwhile, is the clear and concise theoretical analysis of Browning (Browning 1975). The rational voter in this model participates in a one-time vote about the parameters of the social security system (for the sake of simplicity, we focus on pension systems only), and each voter is driven by self-interest corresponding to their age. Elderly voters - pensioners - thus vote for large pensions and are not interested in the level of taxes and social contributions. Voters active on the labor market prefer to decrease current taxes and are indifferent about the level of their pensions. However, voters are not only selfish but they are prescient as well, hence those near retirement age would prefer high taxes and pensions as they consider that they would in the long term be better off under this scenario, even considering the present higher level of taxes. Thus, these voters may vote similarly to pensioners out of pure self-interest.

In Browning's model, overspending on social security is caused by current pensioners, and those close to retirement age will vote for a pension system that is unsustainable in the long term to sustain their current pension and well-being at the expense of future generations. ${ }^{2}$ Based on this model, active middle-age voters would also favor a generous pension system, while younger voters would be against it.

2 For a more detailed analysis of this model, see Galasso and Profeta (Galasso and Profeta 2002).

CORVINUS JOURNAL OF SOCIOLOGY AND SOCIAL POLICY VOL. 9 (2018) 2 
Browning's model was later refined, ${ }^{3}$ but its main approach to political economics did not change: the claim remains that the elderly will support an unsustainable pension system, while youngsters may form a voting coalition against free-riding on future generations.

The explanations of such phenomena in classical sociology sharply contrast with self-interest based interpretations of economics. Yet, in our models this self-interest is replaced by a preference for collective interest representation based on class-consciousness. ${ }^{4}$ The conclusions of theories based on classconsciousness make similar predictions to those of self-interest-based economic models regarding preferences for intragenerational redistribution. However, conclusions diverge in terms of intergenerational redistribution: class-solidarity may suppress the issues involved in intergenerational redistribution (Street and Cossman 2006). However, many sociologists have previously questioned the political behavioral models that rely on classical class theories and instead projected a struggle between different generations in postmodern welfare states (Foner 1974; Turner 1989, 1998). This model of political sociology is hardly distinguishable from the model of purely self-interest driven voters, yet the thesis of an age-class struggle has largely been rejected in mainstream political sociology (Hamil-Luker 2001; Irwin 1996, 1998; Street and Cossman 2006).

\section{INTERGENERATIONAL JUSTICE: ADVOCACY OF FUTURE GENERATIONS}

Regarding the differences between generations, future generations are mostly at a disadvantage in terms of advocacy. In our study we refer to advocacy in political institutions and decision making as future generations cannot participate in decisions that influence their future lives directly. Future generations do not only include children of below voting age, but also those unborn children whose lives will be affected by any long-term decisions. Although these children currently do not have rights per se, they will have rights in the future that should be respected. ${ }^{5}$ Hence when mentioning 'long-term' effects we refer to those effects that span generations -which the affected generations cannot influence at all.

Hence, the advocacy of future generations is hindered by the partial impossibility of interacting with the current (voting) generations. For the former

3 For example, on the inclusion of the combined effect of in-family altruism and material inequalities, see Tabellini (Tabellini 2000).

4 See Manza and Brooks (Manza and Brooks 1999) for an overview.

5 For a thorough discussion of the future rights of children yet unborn, see Tremmel (Tremmel 2006). 
it is physically impossible to sanction any decision by current generations which might hurt them in the future - such decisions include economic decisions (superfluous state overspending), as well as environment-related decisions (deforestation, or the overuse of polluting technologies). Either decision could damage the well-being of future generations compared that of current generations. The self-advocacy of children would theoretically be possible, but of course children are usually not mentally mature enough to perceive the magnitude and consequences of such decisions. For the unborn, the option is not even theoretically possible.

In the following section we mention a few of the institutions dedicated to advocating for the rights of younger generations with the goal of dealing with the above-mentioned challenges. We describe two approaches: the representation of future generations via voting rights or institutions; and legislative constitutional and institutional barriers. Although our study focuses on voting-rights-related issues, we consider it important to have a brief look at other methods of representation. ${ }^{6}$

\section{REPRESENTING FUTURE GENERATIONS - POLITICALLY, LEGALLY AND CONSTITUTIONALLY}

Future generations can be represented directly by legal personnel or institutional bodies. In practice, such representation includes parliamentary advocates, or different committees (including environmental or economic committees). In the case of such forms of representation, although future generations are represented by the living and the issues under debate may be analyzed from the perspective of future generations specifically, the former do not participate in nominating the actual decision-making bodies. However, they may have veto-rights and some limited authority in decision-making. Thus, the most important prerequisite of such a representational body is political independence.

A typical solution for the institutional representation of future generations in decision making is representation through fiscal councils and authorities (Debrun and Kumar 2008; Hagemann 2010). The activities of such bodies may include producing forecasts, reviewing budgetary planning, and even actual participation in decision-making. The most significant advantage of independent fiscal councils is that fiscal policy can thus be made independent from political cycles, hence better fiscal discipline can be created - provided that councils are

6 These methods are discussed in detail by Jakab (Jakab 2016)

CORVINUS JOURNAL OF SOCIOLOGY AND SOCIAL POLICY VOL. 9 (2018) 2 
indeed independent and possess sufficient authority with fiscal policy. There are many examples of such fiscal councils in EU countries, most of which play an advisory role in budgetary planning (Hagemann 2010). In Hungary, the Budgetary Council (Költségvetési Tanács) was founded as such an institution in 2008, and makes proposals about annual budgets.

Future generations can also be represented by other committees and advocates (ombudsman) that are not necessarily related to fiscal policies. Examples include New-Zealand, Canada (commissioners) and Israel, Brazil, Germany, and Chile (committees). Unfortunately, Hungary is not among these countries, as while one such institute did exist (the institute of the Ombudsman for Future Generations (Jávor 2006; Jövő Nemzedékek Országgyülési Biztosa 2008) it was abolished in 2012 and was integrated into another institution that works with fundamental rights and has no specific focus on future generations, the Ombudsman For Fundamental Rights (Fülöp Sándor 2012).

It is easier to find examples of legal representation. In several legal cases a multitude of bodies have represented the interests of future generations (in these cases, the future generations were interpreted as the plaintiffs): federal states in the USA (Göpel 2009), a special court body in Australia (Department of Justice and Attorney General 1979), and simply a group of children in the Philippines (The Supreme Court of the Philippines 1993). In other cases, a single person (amicus curiae) whose knowledge may contribute to understanding the details of the case from the perspective of future generations may assist the work of the court. Strictly speaking, the animus curiae is not a direct representation of future generations, but rather a professional form of court support with a focus on upholding the interests of future generations (for a few recent examples, see Center for International Environmental Law 2017; Our Children's Trust 2016).

The constitutional representation of future generations is also considered a form of legal representation. This usually covers the recognition of general responsibility towards future generations (as in the constitution of the Czech Republic, Poland, and Switzerland) or environmental responsibility (Italy, Netherlands, and Latvia). Debt brakes and upper limits on state deficits in constitutions (Finland, Germany, and Poland) should also be considered a form of representation of future generations, as respecting these limitations is in their interest.

Hungary's constitution also includes several paragraphs similar to these mentioned above - involving the need for the protection of environmental and cultural goods, the call for restrictions on the size of the state debt, and principles for the use of public property. The role of the Parliamentary Commissioner of Future Generations was taken over by the Commissioner of Fundamental Rights and its institutional background, although enforcement of the constitutional clauses faces several obstacles not discussed here. 


\section{REPRESENTATION OF FUTURE GENERATIONS - VOTING RIGHTS}

Providing the right to vote to children and delegating that right to their legal parents was proposed by Paul Demény (Demény 1986) and became publicly known as "Demeny-voting" (or "proxy-voting"). Among the three voting right reforms investigated in this paper, this approach has sparked the most debate and come closest to actually being introduced.

In the original concept, children are provided with a vote that is split between parents until the child reaches voting age. The proposal can easily be applied to to non-conventional families. The true novelty of this proposal is not that a child's right is transferred to the parent, but that children are included among voters. This does not involve the direct representation of children, and does not address those not yet born, but we can assume that parents would cast votes so as to represent the interests of their children and other descendants.

The introduction of Demeny-voting was considered in several countries as a means of representing future generations, including Japan (Aoki and Vaithianathan 2009, 2010; Vaithianathan, Aoki, and Sbai 2013), Germany (Deutscher Bundestag 2003), and Austria (Vanhuysse 2013a). For various reasons, this proposal was not finally introduced.

A common counter-argument is that parents may not be competent to cast their children's vote; furthermore, they could abuse this extra vote in their own self-interest. The first counter-argument may easily be refuted with the argument that if parents were unable to assess the effects of any political or economic decisions on their children's well-being, they would similarly be incapable of doing this for themselves. Following this counter-argument, parents' own rights to vote are made questionable.

In terms of parents misusing their children's votes, there is some evidence that parents would cast the votes of their children for a different party than the one they would personally vote for (Aoki and Vaithianathan 2012). In the related study, more than one-tenth of respondents engaged in such behavior. However, these results do not document if the other respondents considered their own preferred party as a good alternative for their children, or if they were indifferent in this regard. Regardless, this experiment shows that voters would be willing to consider the interest of their children.

Besides this issue, there are other challenges to Demeny-voting. Governments may make decisions that affect not only the living, but also those not born yet. Extending and delegating voting rights would not be a solution to this. Another technical issue would be applying Demeny-voting to non-conventional families such as households with one parent, step-parents, and orphanages. 
Another option for empowering younger generations in a voting system is age-weighted voting. In this system the weight of an individual vote depends on the voter's age. The basis of this idea is that younger voters have to live with the consequences of their votes for longer than elderly voters. Such reforms have not made their way into scientific discussions, but are the subject of media interest (Martin Hiesboeck 2016; Moraro 2016) and are presented as an interesting alternative. A recent analysis of the Brexit vote raises the issue of the potential consequences of using weighted votes to decide about issues of a similar historical weight (Nouvellet 2017).

Alongside these possibilities, lowering the voting age in general often also arises as an alternative. There are a few examples of places where voters of less than 18 years old are allowed to vote (16 yrs: Austria, Brazil, Cuba, Somalia, Nicaragua; 17 yrs: East-Timor, Indonesia, Sudan, North-Korea), while in Germany the same was suggested regarding local elections (reducing the voting age to 16 years). Evidence for the positive effects of lowering the voting age is mixed. (Bergh 2013; McAllister 2014; Wagner, Johann, and Kritzinger 2012; Zeglovits and Zandonella 2013). Some studies find that that lowering the voting age increases the maturity of the youngest voters (at the age of 16), while others do not find evidence for this. Nonetheless, the common goal of these approaches is to foster the engagement of youth in democratic processes.

\section{INTERGENERATIONAL JUSTICE AND PUBLIC OPINION: EARLIER FINDINGS AND HYPOTHESES}

In terms of intergenerational justice, young generations (especially those not yet born) are prone to be affected by the kindliness and responsibility of the currently active and the elderly. However, future generations have no influence on the decisions of the former, neither can they sanction decisions that will negatively affect them.

Preferences for intergenerational redistribution have been analyzed through attitudes towards the pension system, and studies have not confirmed predictions based on models premised on self-interest. This does not mean that age is not a main driver of attitudes towards pensions, but the effects of ideological concerns and status properties prove to be much stronger (Boeri, Boersch-Supan, and Tabellini 2002; Boeri and Pestieau 2004; Els, End, and Rooij 2003; Evans et al. 2004; Gelissen 2001; Hamil-Luker 2001; Silverstein et al. 2000; Street and Cossman 2006).

Current trends in economics and sociology highlight the possible impact of some universal moral sentiments driven by concerns of fairness independent of 
self- or class-interest (in Hungarian see [Gulyás 2007]). These desires include a wish to respect "deservingness" and to respond to neediness in terms of the distribution of benefits. Polls indicate that the support of younger generations for the level of benefits for the elderly can be explained by a belief that the elderly have earned their benefits through their lives' work. On the other hand, public opinion is much more divided in the case of benefits for children (the working force of future generations); one selection criterion is often the ethnic background of the family which would potentially benefit.

Both traditional models based on class solidarity and novel models driven by fairness concerns predict that excessive support for the elderly versus future generations is the result of a public discourse that is focused on intragenerational redistribution. People simply do not consider intergenerational justice and simply are not aware of the imbalance caused by redistribution. However, the impact of public discourse on redistribution is recognized in refined models involving voters who are driven by pure self-interest, and individuals who lack information. In the literature such distortions are often assumed, and the dual nature of the welfare state is also emphasized: firstly as a state that redistributes goods from the rich to the poor within generations (a 'Robin Hood' state) but at the same time one which accumulates savings to support a life-course model (a 'piggy bank' state).

Our main thesis which grounds the empirical study can be deducted from this position: the reason for voter negligence of the interests of future generations is that the state's redistribution discourse excludes intergenerational justice concerns, and focuses on the state's 'Robin Hood' function. If intergenerational aspects were present in public discourse, voters would consider the associated moral sentiments as well, hence they would support reforms leading to the better representation of the interests of future generations. These include voting-rights reforms resulting in the greater incorporation of future generations' interests in decision-making, besides direct decisions about redistribution. Basically, we hypothesize that if voters considered these factors, they would vote accordingly.

We analyzed support for such voting-right reforms through an empirical study in which we investigated whether framing of state redistribution dilemmas influences attitudes towards voting-right reforms. More explicitly, the main question was whether raising awareness about intergenerational dilemmas improves sensitivity to future generations' rights and interests.

Such survey-based experiments face two challenges. First, critics of attitude research and framing research often claim that attitude changes due to framing do not model opinion formulation processes in real discourses. They represent ad hoc, short-term effects and respondents adapt to perceived expectations with their responses. Second, the claim is that those respondents who do have their 
opinions influenced by real discourses would not respond to the hypothesized stimuli in the predicted way, although the topics of the frames used in the experiments do affect them.

Both claims represent grave critiques of research that uses framing effects in experiments, but a method has been recently developed to respond to them. The former critiques build on two opposing models of ideal voters and psychological research has identified methods for determining with which model the personalities of respondents can be associated (Matthes 2007). One type of respondent has difficulty formulating opinions and uses easily accessible response patterns when facing non-trivial questions. In other contexts, however, they respond in a different way, without "carrying over" previous responses. Hence, the validity of their survey responses is quite low. These types of respondents are referred to as "memory-based information processors." The second type of respondent easily formulates opinions which are consistent with earlier responses, but which are modified and reevaluated based on new information. The opinions of the latter are changed by simple manipulations only with dificulty, yet their response validity is higher as they are likely to carry over their attitudes to real situations without framing effects. Results from framing experiments are stronger if they involve respondents of the second type.

Considering the above, we formulated our hypotheses. The first assumption was that the discourse about state redistribution focuses mainly on intragenerational dilemmas (the "Robin Hood" state). Thus, our first hypothesis was that, compared to the control group, an intragenerational frame should not have considerable effects (H1). Our second hypothesis was the motivating assumption of our research: we hypothesized that discussion of intergenerational redistribution dilemmas before surveying attitudes towards the aforementioned voting-right reforms would improve support for those reforms (H2). However, considering the multiple approaches to voter behavior we assumed that this effect would be different among generations: weak for the elderly, stronger for the middle-aged, and strongest among the youngest (H3).

An important component of the literature about redistribution preferences is the relationship between ethnic prejudice and welfare preferences. In the literature on intergenerational redistribution, however, this is a marginal topic despite the fact that the theoretical connection is quite strong. However, in the Hungarian policy discourse about voting rights reforms this topic was emphasized. Namely, it has been expressed that providing additional rights to large families would simply increase the political weight of the roma, hence such reform proposals would face serious resistance from prejudiced voter groups. For this reason, we also included the issue of roma and benefits in our experiment as well, wording it in a way that would not present the dilemma as redistribution between roma and non-roma. 
Instead, our ethnic frame only very shallowly suggested a connection between large families in need and the roma. We assumed that the ethnic frame would also decrease support for voting-right reforms $(\mathrm{H} 4)$.

\section{DATA AND METHODS}

The empirical study involved a survey using an online quota sample of 1000 respondents between the end of June and beginning of July 2016. The structure of the sample in terms of age, cohort, and regional distribution resembles the overall Hungarian population. However, given that the sample was conducted online, the proportion of uneducated respondents is lower than in the population overall, thus the raw responses are probably not representative of the population. However, our study does not focus on simple frequencies of responses (it was not designed to be similar to polls which precede referenda, or pre-surveys related to political decisions). Our sole purpose was to investigate the effects of the framing stimuli on responses to our questions (Schuman 2008). Recent results, especially from online surveys, show that the demographic differences between the sample and the population have negligible (or easily manageable) effects on such framing experiments (Mullinix et al. 2015; Weinberg, Freese, and McElhattan 2014).

Our study focuses on possible reforms of the voting-system. We posed three attitude-related questions in relation to topic, asking respondents their opinions about the following reform-related options:

1. For each child below the age of 18 , a family should get an extra vote

2. In referenda that influence the future of the state, the votes of young voters should should be awarded more weight than those of the elderly

3. Similarly to in Austria, the voting age should be decreased to 16 years old

Respondents reported their level of their agreement using a four-item Likertscale. The three responses were processed into a composite variable that located respondents on an opinion-dimension defined by the factor analysis of responses to individual questions. We assumed that this latent dimension would measure the strength of opinions about the principle of improving future generations' representation, separating this from specific aspects related to the survey questions. This factor score variable was our dependent variable and was present on the left side of our regression model.

Our experiment focuses on examining framing effects on political opinion. We created four random subgroups for the sample (250 respondents each; quotas were used regarding demographic properties on the total sample but not 
on these sub-samples). Besides the control group one group was exposed to intergenerational and another one intragenerational frames during the survey, while the third group was exposed to a frame that was aimed at artificially creating associations between large families in poverty and the roma (we refer to this as 'ethnic treatment'). The respective frames were employed at the beginning of the survey for the inter- and intragenerational redistribution groups, while the 'ethnic treatment' involved priming questions throughout the survey as a treatment. Following exposure to the frames, respondents were asked to respond to various questions about public policy and politics.

The framing consisted of two steps. First, an information video was shown to respondents with related infographics and an explanation of the respective dilemmas. ${ }^{7}$ The videos did not contain potential solutions, but only factual statements (numerical information), and exposed the dilemma of redistribution between old vs. young followed by rich vs. poor. The video was followed by a series of questions about attitudes towards redistribution, as outlined in the framing. Another set of questions then followed about redistribution in general, and only after these questions were the actual voting-right reform questions presented. In the ethnic treatment there was no informational video, and nor were respondents asked questions about redistribution from an inter/intragenerational perspective. Instead, this group answered a series of attitude questions about the poor and recipients of benefits, wherein stereotypical statements about roma and benefit recipients followed each other.

The information videos attempted to encourage respondents to think about the redistribution dilemmas presented therein, while the ethnic treatment was not specifically designed to provoke conscious association between the two factors.

\section{RESULTS}

As previously described, the respondents in our sample were asked three questions related to voting rights. The first one was about providing voting rights to parents, the second proposed increasing the weight of young generations in votes, while the third involved decreasing the voting age to 16 years following the example of Austria. Responses ranged from fully support to completely reject on a 4-level scale.

7 The video-vignette of the intragenerational redistribution frame is available here: https://www.youtube.com/watch? $\mathrm{v}=\mathrm{oVjMlSmcooI}$

The video-vignette of the intergenerational redistribution frame is available here: https://www.youtube.com/watch?v=vLIiqdDNycs 
Respondents in general rejected each proposal. Giving additional voting rights to parents with underage children in the family was rejected by $62 \%$ of the control group (without framing), and only $17 \%$ of respondents agreed with this proposal to a smaller degree. Similarly, the proposal to increase the weight of younger generations' votes was rejected by $56 \%$ of the control group and only one in six respondents agreed with it to a lesser degree. For both questions, $6 \%$ supported the proposals completely. Decreasing the voting age was also rejected by the majority of respondents (38\% completely against, $32 \%$ supported, and only $12 \%$ expressed full support). In the control group, $30 \%$ were strictly against each proposal. However, in our sample $43 \%$ of the respondents agreed at least to a small degree to at least one of the proposals.

These proportions may indicate current trends, yet the results should be handled with care, and not only because of the small sample size (the control group consisting of 250 respondents). Our online sample that was optimized for this survey experiment did not properly represent the adult population in some important respects. Most importantly, educated respondents were over-represented in our sample. Note that those with low level of education (who did not graduate from high school) are more supportive of these proposals than educated respondents.

As mentioned before, we used regression models to investigate the effect of framing on attitudes to maintaining the status-quo of intergenerational relations. The dependent variable in these regression models was a composite variable constructed by factor analysis of the three responses. The variable was standardized with higher values denoting "gerontocratic" preferences aimed at conserving the status quo, while low values express a preference for providing future generations and younger voters with more weight.

The first table contains three linear regression models which approximate the effect of experimental manipulations on preferences about voting rights based on the data from the sample. The first model compares the responses of the control group with the responses of the treatment groups (the simplest test of our second hypothesis, H2). The second model examines our hypotheses about the age-group dependent effects of age and framing ( $\mathrm{H} 1$ and $\mathrm{H} 3)$.

In our experiment, many respondents were excluded from the sample due to the limitations of their devices (cell phones, typically) and were substituted by others. The most interesting effect of this is the under-representation of young respondents in the groups with treatments involving information videos. But there were other less obvious differences due to the selection effects of the device on which the online survey was responded to. In order to control for such problems, we also estimated a model enriched with sociodemographic controls. We consider that this model best estimates the experimental effects, thus we focus on the results of it below - note that there are no differences between the second and the 
third model with respect to the conclusions about experimental effects. The fit of the models shows that the explanatory power of the experimental treatments are quite low. The same holds for our model that includes an extended set of control variables (sex, education, income, residence, labor market status, household size, underage children, siblings, partisan and ideological position, faith). ${ }^{8}$

Table 1. Support for voting-rights reforms (composite dependent variable). OLS regression estimations, full sample.

\begin{tabular}{|c|c|c|c|}
\hline & $\begin{array}{c}(1) \\
\text { Model } 1 \\
\end{array}$ & $\begin{array}{c}(2) \\
\text { Model } 2 \\
\end{array}$ & $\begin{array}{c}(3) \\
\text { Model } 3 \\
\end{array}$ \\
\hline \multicolumn{4}{|l|}{ Experimental manipulation } \\
\hline Intergenerational frame & $\begin{array}{c}0.129 \\
(0.149)\end{array}$ & $\begin{array}{l}0.136 \S \\
(0.271)\end{array}$ & $\begin{array}{c}0.118 \S \\
(0.326)\end{array}$ \\
\hline Intragenerational frame & $\begin{array}{l}0.0379 \\
(0.672)\end{array}$ & $\begin{array}{l}0.108 \S \\
(0.374)\end{array}$ & $\begin{array}{c}0.0886 \S \\
(0.457)\end{array}$ \\
\hline $\begin{array}{l}\text { 'Roma= poor large families' frame } \\
\text { - middle-aged }\end{array}$ & $\begin{array}{l}0.0673 \\
(0.452)\end{array}$ & $\begin{array}{r}0.0852 \\
(0.480) \\
\end{array}$ & $\begin{array}{l}0.0820 \\
(0.490) \\
\end{array}$ \\
\hline \multicolumn{4}{|l|}{ Age group } \\
\hline Young: $18-29$ years & & $\begin{array}{l}-0.123 \\
(0.413)\end{array}$ & $\begin{array}{l}0.0105 \\
(0.952)\end{array}$ \\
\hline Old: 60 -x years & & $\begin{array}{c}0.202 \\
(0.212)\end{array}$ & $\begin{array}{l}0.0700 \\
(0.706) \\
\end{array}$ \\
\hline \multicolumn{4}{|l|}{ Interaction: experimental manipulation $X$ age } \\
\hline Intergenerational\#Young & & $\begin{array}{l}-0.464 * \\
(0.0700)\end{array}$ & $\begin{array}{l}-0.442 * \\
(0.0796)\end{array}$ \\
\hline Intergenerational \#Old & & $\begin{array}{l}-0.0218 \\
(0.918)\end{array}$ & $\begin{array}{c}-0.0542 \\
(0.793)\end{array}$ \\
\hline Intragenerational \# Young & & $\begin{array}{l}-0.254 \\
(0.303)\end{array}$ & $\begin{array}{l}-0.209 \\
(0.387)\end{array}$ \\
\hline Intragenerational \# Old & & $\begin{array}{l}-0.237 \\
(0.266)\end{array}$ & $\begin{array}{l}-0.238 \\
(0.255)\end{array}$ \\
\hline Poor Roma \# Young & & $\begin{array}{l}-0.126 \\
(0.564)\end{array}$ & $\begin{array}{l}-0.113 \\
(0.597)\end{array}$ \\
\hline Poor Roma \# Old & & $\begin{array}{l}-4.19 \mathrm{e}-05 \\
(1.000)\end{array}$ & $\begin{array}{l}0.0221 \\
(0.921)\end{array}$ \\
\hline Constants & $\begin{array}{l}-0.0586 \\
(0.355)\end{array}$ & $\begin{array}{l}-0.0687 \\
(0.424)\end{array}$ & $\begin{array}{l}-0.683^{*} \\
(0.0839)\end{array}$ \\
\hline $\mathrm{N}$ & 1,000 & 1,000 & 1,000 \\
\hline R2 & 0.002 & 0.028 & 0.111 \\
\hline Controls & NO & NO & YES \\
\hline
\end{tabular}

p values in parentheses $* \mathrm{p}<0.1, \S$ Effect size for middle-aged respondents

8 Based on our approximations, the statistical power of a sample size of 1000 is considerable. The model that includes the control variables in the table below would be able to reveal the effects of the intergenerational frame at $80 \%$ probability even if the model's explanatory power improved by $0,7 \%(\mathrm{R} 2)$. This is the explanatory power of this frame among younger respondents. An effect causing a $2 \%$ increase in R2 could be shown in such a sample with $99.5 \%$ probability - using the estimation methods in STATA; results can be found here: https://rive.google.com/file/d/0BqpUqAOfZ1pb1FEc19NUHczeDA/view?usp=sharing 
We analyzed the effect of the experimental manipulation separately for younger (18-29 years old), middle-aged (30-59 years old) and elderly (60+ years old) respondents. Estimations using these age groups indicate that mentioning stereotypes against roma and large families did not significantly influence attitudes towards the reforms. Those who were exposed to such stimuli did not support the status quo more than those in the control group. The effect size is comparable to that for political orientation (and not significant statistically).

The voting-rights preferences of respondents who participated in the intragenerational treatment did not differ significantly from the preferences of those in the control group. The opinions of younger and elderly respondents changed positively due to the treatment, but there were no changes in the case of middle-aged respondents. The influence of the intragenerational experimental manipulation was not significant in either group.

Our study focuses mainly on the effects of the treatment with the intergenerational frame. The middle-aged respondents in this group swung slightly towards rejecting the reforms, yet for the elderly the effect was barely noticeable (the effects and the difference between these two generations are not significant). Younger voters were significantly affected by the intergenerational frame, suggesting more support for their own interests and those of future generations, resulting in support for the voting rights reforms that were proposed. However, the effect is small as well, as shown in the third column of Table I (the parameter estimation of the interaction variable shows the effect of the frame in comparison with that for the middleaged generation). The framing practically shifted the opinions of the younger respondents with a third of the standard deviation.

To sum up, we conclude that the treatments did not have considerable effects on the opinions of respondents, except for the younger ones whose opinions were affected by the intergenerational frame. Note though that we cannot accept responses to questions about such complex and abstract matters without skepticism. The paradigm of standard survey-based attitude-related research is often criticized by questioning the external validity of research into abstract issues that do not exist in everyday life. We rely on another type of critique that emphasizes that there are numerous differences between people when it comes to revealing their opinions and thinking about such complex questions (Bizer et al. 2006). Critics claim that a considerable fraction of respondents have difficulties formulating opinions about such matters. Their responses concerning such topics are rather ad-hoc and less consciously arrived at. Another fraction of people more consciously form their opinions and it is more difficult to artificially divert them using latent stimuli. Due to this conscious process of opinion formation they may react better to explicit information that requires rational reflection. 
In our study we measured the ease of opinion formulation using a set of questions typically used for such purposes in the literature ("need to evaluate" scale [Bizer et al. 2004]) and then split our sample into two (as equally sized as possible). The first part consisted of less conscious respondents, while the second part contained those that had less difficulty with opinion-formulation. We then approximated the same regression models as above for these two subsamples individually, as shown in Table 2.

Table 2. Support for voting-rights reforms (composite dependent variable). OLS regression estimations in subsamples based on respondent types

\begin{tabular}{|c|c|c|c|c|}
\hline VARIABLES & $\begin{array}{c}(1) \\
\text { M2 memo } \\
\text { based }\end{array}$ & $\begin{array}{c}(2) \\
\text { M3 memo } \\
\text { based }\end{array}$ & $\begin{array}{c}\text { (3) } \\
\text { M2 online } \\
\text { proc. }\end{array}$ & $\begin{array}{c}\text { (4) } \\
\text { M3 online } \\
\text { proc. }\end{array}$ \\
\hline \multicolumn{5}{|l|}{ Experimental manipulation } \\
\hline Intergenerational frame - middle-aged & $\begin{array}{c}0.304^{*} \\
(0.0641)\end{array}$ & $\begin{array}{l}0.304^{*} \\
(0.0599)\end{array}$ & $\begin{array}{c}-0.0596 \\
(0.751)\end{array}$ & $\begin{array}{c}-0.0978 \\
(0.599)\end{array}$ \\
\hline Intragenerational frame- middle-aged & $\begin{array}{l}0.0922 \\
(0.588)\end{array}$ & $\begin{array}{l}0.0753 \\
(0.653)\end{array}$ & $\begin{array}{c}0.115 \\
(0.491)\end{array}$ & $\begin{array}{c}0.107 \\
(0.528)\end{array}$ \\
\hline $\begin{array}{l}\text { 'Roma= poor large families' frame } \\
\text { - middle-aged }\end{array}$ & $\begin{array}{c}0.281^{*} \\
(0.0919)\end{array}$ & $\begin{array}{r}0.280 * \\
(0.0933)\end{array}$ & $\begin{array}{l}-0.150 \\
(0.383)\end{array}$ & $\begin{array}{l}-0.126 \\
(0.458)\end{array}$ \\
\hline \multicolumn{5}{|l|}{ Age group } \\
\hline Young: $18-29$ years & $\begin{array}{l}-0.271 \\
(0.213)\end{array}$ & $\begin{array}{c}-0.0583 \\
(0.821)\end{array}$ & $\begin{array}{r}-0.0160 \\
(0.937)\end{array}$ & $\begin{array}{r}-0.0225 \\
(0.924)\end{array}$ \\
\hline Old: 60 -x years & $\begin{array}{l}0.0730 \\
(0.773) \\
\end{array}$ & $\begin{array}{l}-0.0117 \\
(0.967) \\
\end{array}$ & $\begin{array}{c}0.203 \\
(0.326) \\
\end{array}$ & $\begin{array}{r}0.165 \\
(0.504) \\
\end{array}$ \\
\hline \multicolumn{5}{|l|}{ Interaction: experimental manipulationXage } \\
\hline Intergenerational\#Young & $\begin{array}{l}-0.202 \\
(0.541)\end{array}$ & $\begin{array}{l}-0.228 \\
(0.486)\end{array}$ & $\begin{array}{c}-0.909 * * \\
(0.0360)\end{array}$ & $\begin{array}{l}-0.747^{*} \\
(0.0844)\end{array}$ \\
\hline Intergenerational \#Old & $\begin{array}{l}-0.121 \\
(0.710)\end{array}$ & $\begin{array}{l}-0.185 \\
(0.567)\end{array}$ & $\begin{array}{c}0.103 \\
(0.713)\end{array}$ & $\begin{array}{l}0.0728 \\
(0.792)\end{array}$ \\
\hline Intragenerational \# Young & $\begin{array}{l}0.0170 \\
(0.962)\end{array}$ & $\begin{array}{r}-0.0108 \\
(0.975)\end{array}$ & $\begin{array}{l}-0.507 \\
(0.126)\end{array}$ & $\begin{array}{l}-0.444 \\
(0.175)\end{array}$ \\
\hline Intragenerational \# Old & $\begin{array}{c}0.127 \\
(0.701)\end{array}$ & $\begin{array}{l}0.0668 \\
(0.838)\end{array}$ & $\begin{array}{l}-0.483^{*} \\
(0.0777)\end{array}$ & $\begin{array}{l}-0.441 \\
(0.108)\end{array}$ \\
\hline Poor Roma \# Young & $\begin{array}{l}-0.367 \\
(0.240)\end{array}$ & $\begin{array}{l}-0.449 \\
(0.146)\end{array}$ & $\begin{array}{c}0.178 \\
(0.551)\end{array}$ & $\begin{array}{c}0.202 \\
(0.493)\end{array}$ \\
\hline Poor Roma \# Old & $\begin{array}{l}0.0260 \\
(0.939)\end{array}$ & $\begin{array}{c}-0.00229 \\
(0.995)\end{array}$ & $\begin{array}{l}0.0957 \\
(0.743)\end{array}$ & $\begin{array}{l}0.0696 \\
(0.807)\end{array}$ \\
\hline Constants & $\begin{array}{c}-0.242^{* *} \\
(0.0451)\end{array}$ & $\begin{array}{l}-1.150^{* *} \\
(0.0402)\end{array}$ & $\begin{array}{c}0.135 \\
(0.259)\end{array}$ & $\begin{array}{c}0.181 \\
(0.756)\end{array}$ \\
\hline $\mathrm{N}$ & 520 & 520 & 480 & 480 \\
\hline R2 & 0.043 & 0.149 & 0.044 & 0.148 \\
\hline Controls & $\mathrm{NO}$ & $Y E S$ & $\mathrm{NO}$ & $Y E S$ \\
\hline
\end{tabular}

$\mathrm{p}$ values in parentheses $* * \mathrm{p}<0.05,{ }^{*} \mathrm{p}<0.1$

Data show that more conscious respondents were - according to our expectations - more positively affected by the intergenerational frame. Similarly to previous results, the elderly did not react to the frame, and the middle-aged only reacted to a very small degree (not significant statistically) in terms of 
support for voting-rights reforms. Among younger respondents this change is not only statistically significant, but its extent is also approximately one standard deviation for the composite variable that describes support for votingrights reforms. Also, these results are robust for changes in the age groups: the positive effect is observed even when the upper age boundary of the younger age group is increased from 29 years to 34 years.

Investigation of the effects of experimental manipulations in the cases of the different voting-rights reform proposals is also interesting (note that a composite dependent variable was analyzed above). For the reasons outlined above, we only demonstrate regression results for more conscious respondents. The first question concerned voting reform in the shape of giving extra voting rights to parents for their children. Results are very similar to those obtained in the case of the composite variable. Elderly respondents are unaffected by the intergenerational redistribution frame, while it slightly increases support for reforms in the case of the middle-aged and has a significant positive effect for young respondents. Similarly, the intragenerational frame has a positive effect on support of this reform, yet to a much lesser extent.

The second reform addressed the weight of the votes of younger voters. This proposal directly separates the interests of future generations and current generations and creates the biggest contrast between them. Perhaps this was the reason that numerous respondents refrained from responding to support the selfinterest of their own generation. Nevertheless, the effect of age on opinions was not stronger than in the case of the previous question, and the intergenerational frame had smaller effects on younger and middle-aged respondents. The effect of the intragenerational frame was smaller compared to the previous question as well (however, this question apparently had a different effect on the middleaged compared to the elderly and young respondents; this contrast resulted in significant regression parameters).

The third, much less radical form of reform (only marginally related to intergenerational justice) concerned lowering the age of voting. It is not surprising that we did not experience any effect of either frame among the most conscious respondents.

\section{SUMMARY AND CONCLUSIONS}

In our study we investigated the effect of extending voting rights to future generations. From a moral point of view, we may be correct to doubt the wisdom of directly providing voting rights to children (due to their lack of decision- 
making capabilities given their age and maturity), or giving their parents extra voting rights (as parents may abuse this right to pursue their own selfinterests). Despite this, it is clear that while some pillars of the representation of future generations are already defined, these have no influence whatsoever on the course of democratic elections. These pillars include representation in the case of environmental questions (institutions or constitutional barriers), legal representation, and the revisions of some governmental decisions by professional bodies and committees representing future generations (such as monetary councils). Even in these cases the focus is not on giving the choice to future generations, but on influencing issues that could have long-term effects on future generations.

In our empirical study we investigated support for reform proposals that would improve the intergenerational justice of the voting system using an online survey, where we framed this topic in different ways. Our main question concerned the voting rights of children, and we inquired about support for three reform proposals: giving extra voting rights to children (and delegating that vote to parents); changing the weight of the votes of younger voters; and decreasing the voting age.

The first proposal does not involve the explicit participation of future generations in voting, but rather delegates voting rights to parents or other representative institutions. This raises numerous practical questions, but these are outside the scope of our current work. The second proposal would not include children among voters, but would increase the weight of the vote of younger voters to counter the asymmetry due to current negative demographic trends. The third proposal was to include a small proportion of future generations in voting by decreasing the voting age. Attitudes towards these reforms were surveyed using differently framed surveys: one frame emphasized the intergenerational aspects of the welfare system, another frame introduced the intragenerational redistribution dilemma (poor vs. rich), while the third promoted an ethnic focus as well (roma and large families in relief) - here we used a priming technique instead of framing for the survey. Naturally, there was one unframed version of the survey to provide us with a control group.

Results indicate that these proposals are unpopular, irrespective of framing. We found that the interests of future generations were less important to the elderly - however, it is vital to emphasize that these issues are not generally present in public discourse. The purpose of our framing was not to provide information about the topic, but to present various redistribution dilemmas.

Despite our expectations, framing did not significantly change responses, and nor could we identify significant relationships between support for the proposed reforms and some sociodemographic variables. This situation was not improved 
extensively, even by controlling for strong-opinion-formulating voters (the only exception to this were more conscious young respondents). Another surprising result was that ethnic priming did not influence responses either. One may conclude that the problem of representing future generations in the democratic voting system - either directly, or by delegating votes - is so removed from everyday issues that a typical survey respondent may not be able respond in a meaningful way.

\section{REFERENCES}

Alesina, Alberto and Guido Tabellini. 1990. 'A Positive Theory of Fiscal Deficits and Government Debt'. The Review of Economic Studies 57(3):403-14.

Aoki, Reiko and Rhema Vaithianathan. 2009. Is Demeny Voting the Answer to Low Fertility in Japan? PIE/CIS Discussion Paper. 435. Center for Intergenerational Studies, Institute of Economic Research, Hitotsubashi University.

Aoki, Reiko and Rhema Vaithianathan. 2010. Political Economy of Low Fertitlity and Aging. PIE/CIS Discussion Paper. 435. Center for Intergenerational Studies, Institute of Economic Research, Hitotsubashi University.

Aoki, Reiko and Rhema Vaithianathan. 2012. 'Intergenerational Voter Preference Survey - Preliminary Results'.

Arnell, Nigel W. 1999. 'Climate Change and Global Water Resources'. Global Environmental Change 9(Supplement 1):S31-49.

Bergh, Johannes. 2013. 'Does Voting Rights Affect the Political Maturity of 16- and 17-Year-Olds? Findings from the 2011 Norwegian Voting-Age Trial'. Electoral Studies 32(1):90-100.

Bizer, George Y., Jon A. Krosnick, Allyson L. Holbrook, S. Christian Wheeler, Derek D. Rucker, and Richard E. Petty. 2004. 'The Impact of Personality on Cognitive, Behavioral, and Affective Political Processes: The Effects of Need to Evaluate'. Journal of Personality 72(5):995-1028.

Bizer, George Y., Zakary L. Tormala, Derek D. Rucker, and Richard E. Petty. 2006. 'Memory-Based versus on-Line Processing: Implications for Attitude Strength'. Journal of Experimental Social Psychology 42(5):646-53.

Boeri, Tito, Axel Boersch-Supan, and Guido Tabellini. 2002. 'Pension Reforms and the Opinions of European Citizens'. The American Economic Review 92(2):396-401.

Boeri, Tito and Pierre Pestieau. 2004. 'Silence Is Golden? Assessing the Public Debate on Pension Reform'. Centre for European Policy Studies. Retrieved 
6 November 2017 (https://www.ceps.eu/content/silence-golden-assessingpublic-debate-pension-reform).

Browning, Edgar K. 1975. 'Why the Social Insurance Budget Is Too Large in a Democracy’. Economic Inquiry 13(3):373-88.

Buchanan, James M. and Richard E. Wagner. 1977. Democracy in Deficit: The Political Legacy of Lord Keynes. Emerald Group Publishing Limited.

Center for International Environmental Law. 2017. 'Amicus Curiae Brief'.

Debrun, Xavier and Manmohan S. Kumar. 2008. 'Fiscal Rules, Fiscal Councils and All That: Commitment Devices, Signaling Tools or Smokescreens?' in Proceedings of Banca d'Italia Public Finace Workshop. Rome: Banca d'Italia.

Demeny, Paul. 1986. 'Pronatalist Policies in Low-Fertility Countries: Patterns, Performance, and Prospects'. Population and Development Review 12:335-58.

Department of Justice and Attorney General. 1979. 'Land and Environment Court'. Retrieved 29 April 2011 (http://www.lawlink.nsw.gov.au/lawlink/lec/ 11_lec.nsf/pages/LEC_aboutus).

Deutscher Bundestag. 2003. 'Mehr Demokratie Wagen Durch Ein Wahlrecht von Geburt An'.

Els, P. J. A. van, W. A. van den End, and M. C. J. van Rooij. 2003. Pensions and Public Opinion: A Survey among Dutch Households. 752. Netherlands Central Bank, Research Department.

Evans, M. D. R., Jonathan Kelley, Melbourne Institute of Applied Economic, and Social Research. 2004. 'Assessing Age Pension Options : Public Opinion in Australia 1994-2001 with Comparisons to Finland and Poland'.

Foner, Anne. 1974. 'Age Stratification and Age Conflict in Political Life'. American Sociological Review 39(2):187-96.

Fülöp Sándor. 2012. 'Jövő Nemzedékek Országgyűlési Biztosa - Záróközlemény'. Retrieved 23 October 2018 (http://www.jno.hu/hu/).

Galasso, Vincenzo and Paola Profeta. 2002. 'The Political Economy of Social Security: A Survey'. European Journal of Political Economy 18(1):1-29.

Gelissen, John. 2001. 'Old-Age Pensions: Individual or Collective Responsibility? An Investigation of Public Opinion across European Welfare States'. European Societies 3(4):495-523.

Göpel, Maja. 2009. National Policies \& International Instruments to Protect the Rights of Future Generations. Germany, Hamburg: World Future Council. Gulyás, Attila. 2007. 'A Méltányosságelmélet Alapjai'. Közgazdasági Szemle 52(2):167-83.

Hackl, Franz and Gerald J. Pruckner. 2003. 'How Global Is the Solution to Global Warming?' Economic Modelling 20(1):93-117.

Hagemann, Robert. 2010. Improving Fiscal Performance Through Fiscal Councils. OECD Economics Department Working Papers. OECD. 
Hamil-Luker, Jenifer. 2001. 'The Prospects of Age War: Inequality between (and within) Age Groups'. Social Science Research 30(3):386-400.

Hauert, Christoph, Joe Yuichiro Wakano, and Michael Doebeli. 2008. 'Ecological Public Goods Games: Cooperation and Bifurcation'. Theoretical Population Biology 73(2):257-63.

Irwin, Sarah. 1996. 'Age Related Distributive Justice and Claims on Resources'. The British Journal of Sociology 47(1):68-92.

Irwin, Sarah. 1998. 'Age, Generation and Inequality: A Reply to the Reply'. The British Journal of Sociology 49(2):305-10.

Jávor, Benedek. 2006. 'Institutional Protection of Succeeding Generations Ombudsman for Future Generations in Hungary'. Pp. 282-98 in Handbook of Intergenerational Justice. Cheltenham: Elgar Publishing.

Jövő Nemzedékek Országgyűlési Biztosa. 2008. ‘Jövő Nemzedékek Országgyűlési Biztosa - Politikai Évkönyv - a Jövő Nemzedékek Országgyülési Biztosa Fejezet Politikai Évkönyv 2008'. Retrieved 29 April 2011 (http://www.jno.hu/hu/?\&menu=magunkrol).

Kopits, György. 2007. Fiscal Responsibility Framework: International Experience and Implications for Hungary. MNB Occasional Papers 62. Magyar Nemzeti Bank.

Lumer, Christoph. 2009. 'Climate Change, Intergenerational Justice and Development'. Intergenerational Justice Review 3(3).

Manza, Jeff and Clem Brooks. 1999. Social Cleavages and Political Change: Voter Alignments and U.S. Party Coalitions. Oxford, New York: Oxford University Press.

Martin Hiesboeck. 2016. 'The Age-Weighted Vote'. Retrieved 4 November 2018 (https://www.linkedin.com/pulse/age-weighted-vote-martin-hiesboeck).

Matthes, Jörg. 2007. 'Beyond Accessibility? Toward an on-Line and MemoryBased Model of Framing Effects'. Communications 32(1):51-78.

McAllister, Ian. 2014. 'The Politics of Lowering the Voting Age in Australia: Evaluating the Evidence'. Australian Journal of Political Science 49(1):68-83. McQuilkin, Jamie. 2018. 'Doing Justice to the Future: A Global Index of Intergenerational Solidarity Derived from National Statistics'. Intergenerational Justice Review 12(1).

Moraro, Piero. 2016. 'Younger Citizens Should Have More Votes than Those over 60'. The Sydney Morning Herald. Retrieved 4 November 2018 (https:// www.smh.com.au/opinion/younger-citizens-should-be-allowed-more-votesthan-those-over-60-20160706-gpzq69.html).

Mullinix, Kevin J., Thomas J. Leeper, James N. Druckman, and Jeremy Freese. 2015. 'The Generalizability of Survey Experiments $<$ a Href="\#afn1" $>*</ A>$ '. Journal of Experimental Political Science 2(2):109-38. 
Noord, Paul van den. 1993. Pension Liabilities in the Seven Major Economies /.

Paris : Organisation for Economic Co-operation and Development,.

Nouvellet, Pierre. 2017. 'Age Matters in the UK's Brexit Referendum'. Significance 14(4):30-33.

Our Children's Trust. 2016. 'In RE: National Inquiry on the Human Rights Violations or Threats of Violations Resulting from the Impacts of Climate Change and the Responsibility Therefor'. 19.

Penner, Rudolph G. and Eugene C. Steuerle. 2007. Stabilizing Future Fiscal Policy: It's Time to Pull the Trigger. Text. Washington DC: The Urban Institute. Schuman, Howard. 2008. Method and Meaning in Polls and Surveys. Harvard University Press.

Silverstein, M., T. Parrott, J. j. Angelinni, and F. 1. Cook. 2000. 'Solidarity and Tension between Age-Groups in the United States: Challenge for an Aging America in the 21st Century'. International Journal of Social Welfare 9(4):270-84.

Street, Debra and Jeralynn Sittig Cossman. 2006. 'Greatest Generation or Greedy Geezers? Social Spending Preferences and the Elderly'. Social Problems 53(1):75-96.

Tabellini, Guido. 2000. 'A Positive Theory of Social Security'. The Scandinavian Journal of Economics 102(3):523-45.

The Supreme Court of the Philippines. 1993. 'CRIN - Child Rights Information Network - The Law - Philippines: Minors Oposa v. Secretary of the Department of Environmental and Natural Resources, 1993'. Retrieved 29 April 2011 (http://www.crin.org/Law/instrument.asp?InstID=1260).

Tremmel, Jörg. 2006. Handbook of Intergenerational Justice. Edward Elgar Publishing.

Turner, Bryan S. 1989. 'Ageing, Status Politics and Sociological Theory'. The British Journal of Sociology 40(4):588-606.

Turner, Bryan S. 1998. 'Ageing and Generational Conflicts: A Reply to Sarah Irwin'. The British Journal of Sociology 49(2):299-304.

Vaithianathan, Rhema, Reiko Aoki, and Erwann Sbai. 2013. Support for Franchise Extension for Children: Evidence on Japanese Attitude to Demeny Voting. CIS Discussion paper series. 610. Center for Intergenerational Studies, Institute of Economic Research, Hitotsubashi University.

Vanhuysse, Pieter. 2013a. A Snapshot of Intergenerational Justice: Austria's Performance Compared to Other OECD Countries.

Vanhuysse, Pieter. 2013b. 'Intergenerational Justice in Aging Societies: A CrossNational Comparison of 29 OECD Countries'. SSRN Electronic Journal.

Wagner, Markus, David Johann, and Sylvia Kritzinger. 2012. 'Voting at 16: Turnout and the Quality of Vote Choice'. Electoral Studies 31(2):372-83. 
Weinberg, Jill, Jeremy Freese, and David McElhattan. 2014. 'Comparing Data Characteristics and Results of an Online Factorial Survey between a Population-Based and a Crowdsource-Recruited Sample'. Sociological Science 1:292-310.

Zeglovits, Eva and Martina Zandonella. 2013. 'Political Interest of Adolescents before and after Lowering the Voting Age: The Case of Austria'. Journal of Youth Studies 16(8):1084-1104. 